\title{
Belgesel Filmde Milli Egemenlik ve Örnek Film Çözümlemesi
}

National Sovereignty in Documentary Film: A Sample Film Analysis

\section{Dr. Öğr. Üyesi Erhan YILDIRIM ${ }^{1}$}

Başvuru Tarihi: 17.03 .2020

Kabul Tarihi: 15.04 .2020

Makale Türü: Araştırma Makalesi

Öz

Belgesel sinema toplumsal yaşamın içindedir. Belgesel sinema toplumsal yapının içinde toplumsal sorunları, olayları ve olguları kayıt edip, araştıran, çözümleyen, yorumlayan bir sinema dalıdır. Toplumsal yaşamın içinde kişilerin, grupların ve insan topluluklarının yaşadıkları, acıları, hüzünleri, umutları, mutlulukları, mutsuzlukları, etkinlikleri, faaliyetleri, ürettikleri, kültürleri, örfü, adedi, geleneği-göreneği vardır. Bu dün yaşanan, bugün yaşanmakta olan, yarın yaşanacak olandır. Bu yüzden belgesel sinema toplumsal yaşam içindeki gerçek kişiler, topluluklar, olaylar ve mekanlarla ilgilenen bir disiplin olarak karşımıza çıkar. Belgesel sinema gibi toplumsal yaşam içindeki gerçeklerle ilgilenen bir başka disiplin daha vardır; Tarih Bilimi. Bu çalışmada tarih biliminin içinde Cumhuriyet tarihine geçişte, Türkiye Cumhuriyeti Devleti'nin rehberi ve sigortası olacak olan Milli Egemenlik konusu teorik bazda ele alını değerlendirilmiştir. Çalışmanın teorik kısmında belgesel sinemanın amaçları, türleri, gerçeklik ile olan ilişkisi tartışılmıştır. Tartışılan konular zemininde belgesel sinema ile tarih bilinci arasındaki iliş̧ki incelenmiştir. Tarih bilincinin oluşturduğu milli egemenlik şuuru üzerine inşa edilen 23 Nisan Ulusal Egemenlik ve Çocuk Bayramı isimli belgesel film amaçlı örneklem kapsamında seçilmiştir. Çalışmanın çözümlemesinde göstergebilim analiz yöntemi kullanılmıştır.

Anahtar Kelimeler: Belgesel Sinema, Milli Egemenlik, Milli Şuur

\footnotetext{
${ }^{1}$ Erciyes Üniversitesi, Güzel Sanatlar Fakültesi Görsel İletişim Tasarımı Bölümü, erhany@erciyes.edu.tr, ORCID: 0000-0002-8784-6687
} 


\section{Abstract}

Documentary cinema is integrated in social life. Documentary cinema is the cinema branch that records, investigates, analyzes, and interprets social problems, events and facts within the social structure. In social life, there are suffering, sadness, hopes, happiness, unhappiness, activities, products, cultures, customs and traditions of people, groups and human societies. This is what happened yesterday, what is happening today, and what will happen tomorrow. For this reason, documentary cinema appears before us as a discipline dealing with real people, societies, events and places in social life. There is another discipline also dealing with the realities of social life like documentary cinema; Science of History. In the present study, the National Sovereignty, which will be the guide and insurance of the State of the Republic of Turkey, was discussed and evaluated on a theoretical basis in the transition to the Republic in the Science of History. The aims, types and relations of documentary cinema with reality were discussed in the theoretical part of the study. On the basis of these topics discussed herein, the relation between documentary cinema and history awareness was also examined. The documentary film "April 23, National Sovereignty and Children's Day", which was established on the consciousness of national sovereignty formed by the consciousness of history, was selected for the study within the Purposeful Sampling Method. A sample film analysis was conducted in the study by using the Semiology Analysis Method.

Keywords: Documantery Film, National Sovereignty, National Consciousness

\section{Giriş}

Belgesel, insana dairdir. Belgesel, hayata dairdir. Belgesel, evrene dairdir. Belgesel, yaşanmış olana, yaşanmakta olana dairdir. Belgesel, insan, toplum, evren, hayat, geçmiş, şimdi, gelecek ile ilgili her şeye dairdir. Yaşama dair her şeyin fotoğrafını çeken belgesel, hayatın sorgulamasın1, analizini yapar. Belgesel, izleyicisine görünmeyeni göstermek, fark edilmeyeni fark ettirmek, hissedilmeyeni hissettirmek, sorgulanmayanı sorgulatmak, konuşulmayanı konuşturmak, vb. işleve sahiptir (Yıldırım, 2019, s. 136). Çünkü belgesel sinemanın temeli insana ve topluma dayanır. Belgesel sinemanın varoluş nedenlerinden biri toplum ile kurduğu ilişkidir, bu bağlamda belgesel sinema bir sanat formu olarak toplumsal yapıyla diğer sanatlara oranla daha doğrudan bağlar kurmakta ve bu yapıyı daha dolaysız biçimde yansıtmaya çalışmaktadır (Aytekin, 2013, s. 3). Toplumsal yapının yansıtılmasında belgesel sinema, hayatın aynası, evrenin projeksiyonu gibi işlev görür. Belgesel sinema insanların arasında yaşamın fotoğrafını çeker. Çekilen fotoğrafın içinde kişiler, gruplar, topluluklar, ülkeler vardır. Kişilerin ve kişilerin oluşturduğu insan yığınlarının yaşanmışlıkları, yaşadıkları ve yaşayacakları vardır. Belgesel sinemaya farklı kuramcı, belgeselci ve akademisyenin getirdiği tanımlamalar ve bakış açıları konunun zenginleşmesine önemli katkılar sunacaktır.

Rotha'ya göre (2000, s. 48), belgesel sinema bir yönetmen için düşüncelerini ifade noktasında ve toplumun bakışlarını belli bir konu üzerine odaklamada güçlü bir araç konumundadır. Aufderheide'e göre (2007, s. 2) belgeseller gerçek hayat hakkındadır, onlar gerçek hayat 
değildir. Hatta gerçek hayata açılan bir pencere bile değildir. Sadece gerçek hayatı ham madde olarak kullanarak gerçek hayatın portrelerini sunarlar. Nazmi Ulutak (1988, s. 11), belgesel sinemayı insan odaklı olarak ele alıp, "insanların birbirleriyle ve çevreleriyle ilişkilerinden doğan, günlük yaşam içindeki çeşitli toplumsal sorunları, olayları ve olguları kayıt eden, araştıran, çözümleyen, yorumlayan bir film türü olarak tanımlamıştır. Adalı belgesel sinemaya yorumlayııı bir bakış açısı ile yaklaşmıştır. Adalı (1986, s. 14), belgesel filmi, yeryüzünün herhangi bir bölgesindeki insanların sorunlarının, gerçek kişiliklerinin ve yaşama biçimlerinin üstüne çağdaş bir yorumda bulunmak üzere ciddi bir girişim yapan çalışmalar olarak ele almıştır. Süha Arın, belgesel filme sanatsal bir boyut katarak belgeseli, tıpkı mimaride olduğu gibi, bilimle sanatın dengeli bir biçimde yer aldığı bir yapı olarak açıklamaktadır (Esen, 1998, s. 5-6). Grierson, belgesel filmi sinema sanatının içerisinde bir yaklaşım biçimini temsil eden bir sanatsal eser olarak görürken; sanatı gerçekliği gösteren bir ayna değil, ona şekil veren bir çekiç olarak nitelemektedir (Rabbiger, 1998, s. 18).

Belgesele ilişkin görüşlerin bir kısmı ise daha çok belgeselin işlevi üzerine odaklanmaktadır. Zaur Mükerrem (2015, s. 25) belgeseli, bilgi veren, eğiten, kültür aşılayan, sanat seviyesine varabilen bir yaratıcı faaliyet olarak tanımlamaktadır. Belgesel filmin birey için kaçış değil, tam tersine bir buluş, yeniden keşfediş ve buluşma olduğunu düşünen Nilüfer Pembecioğlu (2005, s. 2), belgesel film, kimileri için gerçeği olabildiğince gerçeğe uygun sergileyebilme amac1, kimilerine göre ise gerçeklerin bireyin gündemine yerleştirilmesi için bir araç konumunda olabilir demektedir. Pembecioğlu (2005, s. 1), bireylerin toplumsal yapıyı, ilişkileri, kurumları ve kendini anlaması, geçmişi ve şimdiyi daha bilinçli bir biçimde yorumlayacak ve geleceğe kestirim yapabilecek bir bakış açısı geliştirebilmesi belgesel sinemanın hem mümkün kıldığı bir olanak hem de ulaşmaya çalıştığı hedeflerden biridir diyerek belgesel amaçlarına yönelik bir açıklamada bulunmuştur.

Belgeselin hedeflerini, işlevlerini ve hedeflediği kitlesini kendisine referans alarak yapılan tanımlamalardan ve açıklamalardan yola çıkarak belgesel filmde milli egemenlik kavramını uygun bir zemine oturtabilmek için konumuza belgesel türlerini ana başlıklar altında sıralayarak devam etmek uygun olacaktır.

\section{Belgesel Film Türleri}

Belgeselin türlerini farklı kuramcılar farklı sınıflandırmalar içinde ele alarak değerlendirmişlerdir. Bu konuda Wolf Rilla, Bill Nichols, Eric Barnouw ve Roy Paul Madsen'in belgesel türleri konusunda yaptıkları farklı sınıflandırmalar ele alınacaktır.

Wolf Rilla (1974, s. 119) belgeselleri, film gazeteciliği, genel konulu filmler, doğa belgeselleri, belli bir amaca yönelik belgeseller, sponsor destekli belgeseller, eğitim filmleri ve sinemagerçek olarak amaçlar noktasında sınıflandırmıştır.

Nichols (1991, s. 32) belgesel filmde, tekstlerin yapılandığı ve baskın düzenleme örnekleri denilebilecek dört sunum yöntemi olduğunu savunmuştur. Bunları, açıklayan, gözlemci, etkileşimli, yansıtıcı yapı olarak dört farklı belgesel yöntemine ayırmıştır. 
Barnouw'un belgeselci kimliklerine göre yaptığı sınıflamayı on iki başlık altında toplamak mümkündür. Bunları, keşif belgeselleri, muhabir geleneğindeki belgeseller, resim geleneğindeki belgeseller, taraf tutan belgeseller, savaş propagandası belgeselleri, savaş suçları üzerine belgeseller, şiir geleneğindeki belgeseller, tarihi derleme belgeseller, sponsor desteğiyle gerçekleştirilen belgeseller, gözlemci belgeseller, katalizör belgeseller ve gerilla belgeselleri olarak sınıflamak mümkündür (Çakaroz, 2008, s. 21).

Roy Paul Madsen, The Impact of Film kitabında belgesel filmi her biri farklı bir ülkeyi temsil eden beş ayrı gruba ayırır. Madsen, Amerika Birleşik Devletleri'nden doğalcı gelenekleri konu alan belgesel, İngiltere'den toplumsal olayları konu alan belgesel, Sovyetler Birliği'nden propaganda ve haber filmlerini konu alan belgesel, Fransa ve Almanya'dan gerçekçi belgesel olarak sınıflandırmıştır (Morva, 2003, s. 26).

Belgesel sinemanın gelişim süreci incelenerek ilgili literatür tarandığında, kuramcıların belgesel filmleri biçim, içerik ve tarihsel gelişim sürecine göre değişik türlere ayırdığı görülmektedir. Demir çalışmasında $(2015$, s. 87) içeriğe göre yapmış olduğu sınıflandırmada belgesel türlerini, haber belgeseli, gezi belgeseli, doğa belgeseli, toplumsal belgesel, araştırma belgeseli, bilimsel belgesel, tarih belgeseli, savaş belgeseli, biyografi belgeseli ve propaganda belgeseli olarak sınıflandırmıştır.

\section{Belgesel Filmlerin Anlatı Yapısı}

Belgesel filmler önceden kurgulanmış, planlanmış, düşünülmüş, verilmek istenilen duygu ve düşünceye göre üretilmiş yapımlardır. Bu yapımlarda belgeselin dili görsel bir dil olduğu için anlama değil, anlatma önem kazanmıştır. Bu yüzden de yönetmen, yapımcı ve senaristin yazdığı, çektiği, kurguladığı, ürettiği mesajların oluşumunda hedef kitlenin zevk ve beğenileri değil, yapım ve yaratım ekibinin içinde yer alan kişilerin tercihleri etkili olmaktadır (Yıldırım, 2019, s. 139). Rotha'ya göre (2000, s. 128) yaratıcı yorum, belgesel filmlerde görüntünün anlattığı şeye dikkat çekmelidir. Anlatı sırasında belgesel sinemacı dış gerçekliğin kendisini görüntülemektedir. Görüntülemede mekân, ortam, uzam, araç, dil önemlidir. Her mekânın, aracın ve ortamın ayrı bir dil konuştuğu varsayıldığında, belgesel filmlerde de, yayınlandıkları her mecraya göre, içerik dilinin, anlatım şeklinin değiştiği söylenebilir. Anlatı dili, aynı zamanda belgeselin yayınlandığı ortamla da paralellik gösterir. Belgesel film yönetmenleri için de önemli olan bu dilin nasıl kullanıldığıdır.

Belgesel filmler için bir anlatı yapısı oluşturma noktasında Erol Mutlu'nun televizyon programları için geliştirmiş olduğu anlatı yapısını belgesel sinemanın diline uyarlamak mümkündür. Televizyon programlarının bütünlüklü yapısının oluşumuna katkı sunan televizyon programlarının anlatı formudur. Televizyonun dilinin ve sunuş biçiminin klasik anlatı formuna uygun bir yapıya sahip olduğu bilinmektedir. Televizyonlar için kullanılan anlatı yapıları belgesel filmler içinde kullanılabilmektedir. Mutlu (1995, s. 73-81) bir televizyon programının üç parçadan oluştuğunu ifade eder. Mutlu'nun televizyon programlarının geneli için yaptığı siniflama; 
a) Açılıș (Tanıtım),

b) Programın gövdesi,

c) Kapanış, kısımlarından oluşmaktadır. Bu anlatı yapısının belgesel filmlerde de kullanılan bir karaktere sahip olduğunu söylemek mümkündür. $\mathrm{Bu}$ anlatı yapısı içindeki bölümleri kısaca aşağıdaki şekilde özetlemek mümkündür (Mutlu,1995, s. 73-81).

\section{a) Açılış (Tanıtım)}

Televizyon programlarının açılışları, programın başladığını haber vermek ve hedef izler kitlenin dikkatini programa çekmek amacını taşır. Açılış türleri çok farklı şekillerde sınıflandırılsa da genellikle tercih edilen, tanıtıcı, soğuk ve karma açılış olarak yapılan sınıflamadır. Belgeseller için tercih edilen yöntem, filmin içinden çekip alınan enstantaneler ile oluşturulan bir açıllış (jenerik) şeklidir.

\section{b) Programın Gövdesi}

Açılışın hemen ardından gelen kısım programın temelini yani gövdesini oluşturur. Programın temelini oluşturan bu kısım aslında içeriğin biçimlendiği ve yoğrulduğu kısımdır. Programın türü ne olursa olsun ana amaç izleyicinin programı izlemesini sağlamak ve ilginin devam etmesidir. Özünde programın gövdesinde yer alan unsurlar izleyici ilgisini sürdürmeye yönelik olmasına karşın, ana amaç mesajların etkili bir biçimde örgütlenmesini sağlamaktır. Bunlar birlik, çeşitlilik, tempo ve doruk noktadır. Sözü edilen gövde içindeki unsurlar belgesel filmlerde de izleyici ilgisini sürdürmek için gereklidir.

\section{c) Kapanış}

Kapanışlar belgesel filmin gerekliliklerini yerine getirmelidir. Belgesel filmin ana gövdesi içinde yer alan doruk noktadan hemen sonra filmin biteceği algısı izleyiciye aktarılmalıdır. Belgesel filmde yapımda ve yaratım sürecinde emeği geçen kişi ve kuruluşların ismi, kapanış jeneriği ile birlikte verilmelidir.

\section{Belgesel Sinema ve Gerçeklik}

Sinema sadece gerçek hayattaki nesneleri, insanları, mekanları değil, olayları ve hareketleri de olduğu gibi yansıtma gücüne sahip bulunmaktadır. Başlangıcından günümüze sinema alanındaki teknolojik gelişmeler, izleyici üzerinde gerçeklik hissinin yaratılmasında artan bir etkiye sahip olmaktadır. Gerçeklik insanın dışında, kendi başına var olan bir dış dünyadan oluşmamaktadır. Aksine gerçeklik insanın bireysel ve toplumsal görüşleriyle belirlenen ve insanın yaşantı ve anlayışıyla katıldı̆̆ı ilişkilerinin toplamından meydana gelmektedir. Sinema tarihinin sessiz sinema döneminden itibaren ortaya çıkmaya başlayan ve konusunu gerçek hayattan alan, gerçekliği kullanış biçimleriyle dikkat çeken ve içindeki malzeme de hayatın kendisi olan belgesel filmin doğuşu, 1920'li yılların ilk yarısına denk gelmektedir. 1930'lu yılların başlarında sinema sanatında Documentary film terimi yaygınlık kazanmaya başlamış, daha sonra bu terim, gerçeğin yaratıcı bir biçimde işlenmesi ve Grierson'un ifadesiyle, gerçeğin yaratıcı bir biçimde yorumlanması şeklinde açıklanmıştır (Adalı, 1986, s. 13).

Flaherty, Vertov ve Grierson belgesel sinemanın gerçekler ile çalışan bir sinema olduğu konusunda hemfikir olmuşlardır. Çünkü belgesel sinema gerçekliğin ortaya çıkarılmasına önemli katkılar sağlamaktadır. Flaherty, yaptığı filmlerle, var olan gerçek yaşamın özelliklerini 
araştırmış gerçeklikten alınan görüntülerle yeni bir sinemasal dünya yaratmaya, belgesel sinema aracılığıyla dünyayı keşfetmeye çalışmıştır (Andrew, 1976, s. 170). Vertov, belgesel sinema ile yaşamın içine girilmesini ve bu konunun araştırılmasını arzulamıştır (Barnouw, 1974, s. 54). Grierson ise belgesel sinemayı gerçekliğin yaratıcı bir biçimde işlenmesi/yorumlanması olarak tanımlamıştır (Ulutak, 1988, s. 65).

Sinema hem içeriği, hem görüntüsüyle gerçek dünyayı olduğu gibi gösterebilecek ayrıcalıklı bir biçim olduğundan, gerçek dünya, gören ve gösteren sanatçının zihninden süzülerek izleyiciye iletilmektedir (Wollen, 2004, s. 148). Sigfried Kracauer, Andre Bazin ve V. F. Perkins gibi kuramcılar sinemanın fark edilebilir bir gerçeklik sunduğunu ve etkileyiciliğinin de bundan ileri geldiğini belirtmektedirler (Baydur, 2004, s. 180). Bülent Vardar (2007, s. 205), belgesel sinemanın amacının, gerçeğe yaklaşmak, dolayısıyla da filmi oluşturma, bilince ayna tutma sürecinde gerçeği değiştirmeden yansıtma ya da gerçeği yozlaştırmadan yorumlama olduğunu belirtmektedir.

Rotha'nın (2000, s. 79) belirttiği gibi genel olarak sinema, tür, format, biçim ayrımına girilmeksizin, üretim koşullarından tüketme biçimlerine varana dek birden fazla bireyin varlığını gerektiren ve şöyle ya da böyle döneminin toplumsal yapısını yansıtan bir kitle sanatıdır. Kitle sanatı olarak yaşanılan dönemin toplumsal yapısını aslını uygun olarak yansıtmaya en uygun sinema türünün belgesel olduğu bilinmektedir.

\section{Belgesel Sinema ve Tarih ilişkisi}

Belgesel sinema ürünleri, toplumsal yapının ve toplumsal değişmenin aynası olmanın ötesinde, neden-sonuç ilişkilerinin izinin sürülebileceği verileri de içinde barındırmaktadır. Gündelik yaşamın, sıradan insanın ve genel anlamda toplumsal yapının ve toplumsal değişimin izlerinin en iyi gözlemleneceği alanlardan birisi belgesel sinemadır. Belgesel sinema, toplumsal değişmenin izlerini ve sonuçlarını kendi bünyesinde barındırır. Bir başka deyişle, bu karşılıklı bir ilişkidir; belgesel sinema, hem toplumsal yapıdaki değişimlerin, dönüşümlerin hem de kendi yapısındaki değişimlerin, dönüşümlerin doğrudan gözlemlenebileceği bir sanat dalıdır. (Aytekin, 2013, s. 3). Bu değişimin ve dönüşümün içinde insan ve insan toplulukları vardır. Belgeselin çalışma alanının temelinde insan, insan toplulukları, olaylar vardır. Geçmişte yaşamış insan ve insan topluluklarının faaliyetlerini ve yaşanmış olan olayları, sebep sonuç ilişkisi kurarak, belge ve bulgular 1şı̆̆ında, yer ve zaman göstererek inceleyen bir bilim dalı vardır, tarih bilimi. Belgeselinde, tarihinde ana malzemesi, insan, insan toplulukları ve belgelerdir. Belgeler tarih biliminde olduğu gibi belgesel sinemanın da en önemli malzemesini oluşturmaktadır. $\mathrm{Bu}$ anlamda belgelemek ve belgelerin korunarak geleceğe aktarılması belgesel sinemacının sorumluluğu altında bulunmaktadır. Belge materyalini kullanarak üretim yapan belgesel sinemacı tarihsel bir sorumluluk altında bulunmaktadır. Çünkü belgeler, korunabildiği sürece bir zaman sonra başka kültürlerin, başka düşüncelerin, başka filmlerin sözcükleri olma şansına sahip olabileceklerdir (Demir, 2015, s. 83). Carr, geçmişin yorumunun anahtarını ancak geleceğin sağlayabileceğini, böylece tarihte nesnellikten söz etmenin olanaklı olduğunu, geçmişin geleceğe ve geleceğin de geçmişe 1şık tutmasıyla tarihin açıklanabileceğini belirtir (Ulutak, 1988, s. 87). Geçmiş ile gelecek arasında kılavuzluk yapıp, toplumları aydınlatacak olan kuşkusuz tarih bilimidir. Goldman tarih incelemesinin temelinde insan topluluğunun dönüşümü bulunduğunu ve toplum üzerine etki yapmış ya da yapmakta olan her şeyin önemli olduğunu söyler (Ulutak, 1988, s. 102-103). Toplum üzerinde etkisi olan ve/ya olabilecek 
konular tarih bilimi için önemli bir konudur. Tarih biliminin temelini oluşturan konu ve/ya konuların belgelenmesi ve kültürel bir miras olarak saklanması ve paylaşılması hiç kuşkusuz sinema sanatının en karakteristik özelliklerinden birisidir. $\mathrm{Bu}$ kültürel mirasın üretimi, saklanması ve paylaşımında en etkili sinema türü belgeseldir. Belgesel sinemanın üzerinde çalıştığı olay ve olgular tıpkı tarih ve toplum bilimlerindeki gibi, toplumsal bir varlık olan insanlar tarafından yaratılır. Bu etkileşimde belgesel sinemanın içinde tarih biliminin amacını, rolünü ve hedeflerini görmek mümkündür.

\section{Tarih Bilinci İçinde Milli Egemenlik}

Milli egemenlik ilkesi Türk devletinin geleceği, garantisi, sigortası olarak görülmesi gereken değerli bir ilkedir. Tarih bilincinin oluşturduğu milli egemenlik şuuru üzerine inşa edilen Ulusal Egemenlik ilkesi Mustafa Kemal Paşa'nın en çok üzerinde durduğu konu idi. Mustafa Kemal Paşa'ya göre milli egemenlik milli meclisin üstünde başka bir gücün olamayacağı fikrine dayanıyordu. Bu bağlamda milli egemenlik, Mustafa Kemal Paşa'nın milli mücadelenin ilk günlerinden itibaren açıkça ortaya koyduğu, 1srarla vurguladığı bir temel ilkedir. Bu ilke Türk Devletinin temel dayanağı ve yapıcı gücüdür. Milli ve egemenlik sözcüklerinin birleşmesinden oluşan milli egemenlik, devlet içinde en üstün buyurma kudreti olarak tanımladığımız egemenliğin, millete ait olduğunu ifade eder (Mumcu vd., 1986, s. 40). Gücünü milletin iradesinden alan Türkiye Büyük Millet Meclisi 100 yıl önce açıldı. Türkiye Büyük Millet Meclisi'nin açılışına kadar ki yapılan kongrelerde ve mitinglerde, milli meclisin varlığı, milli şuurun temsili açısından şart görülmekteydi. Son Osmanlı Mebusan Meclisinin de artık üzerine düşen vazifeleri yapamayacak konuma gelmesi de, milletin iradesini temsil eden, temsilcileri bizzat meclisin içinden çıkmış olan bir meclisin oluşturulmasını kaçınılmaz hale getiriyordu (Göde, 1988, s. 51). Rumeli ve Anadolu toprakları düşman işgali altındaydı. Düşman işgali altındaki topraklarda Mustafa Kemal Paşa'nın önderliğinde Kurtuluş Savaşı'nı başlatacak ve Cumhuriyet'e giden yolda adımlar atılmasını sağlayacak Türkiye Büyük Millet Meclisi, 100 yıl önce 23 Nisan'da açıld1. Türkiye Büyük Millet Meclisi’nin açılışı, kurtuluş mücadelesinin en önemli safhalarından birisi oldu (Özden, 2019).

23 Nisan 1920 tarihinde, Ulus Meydan'ında bugün müze olarak kullanılan bir binada, Türkiye Büyük Millet Meclisi açılmış ve ilk tarihi konuşmayı yapan Mustafa Kemal Paşa Meclis tarafından tutulması gereken yolu açıklamıştır. Hakimiyetin kayıtsız şartsız Türk Milleti'ne ait olduğunu ve Türkiye Büyük Millet Meclisi'nin üzerinde herhangi bir kuvvetin bulunmadığ kabul edilerek, milli irade esas kılınmış ve böylece kesin bir şekilde demokratik hayata geçilmiştir (Göde, 1988, s. 51).

23 Nisan 1920 tarihinde, tüm ülke geneline gönderilen bildirilerle vatandaşlar haberdar edildikten sonra Türkiye Büyük Millet Meclisi resmen açılıyordu. Mustafa Kemal, 24 Nisan 1920 tarihli meclis konuşmasında, milli şuurun oluşturulmasında bir araç olduğunu da belirttiği milli iradeyi yansıtan bağımsız bir meclisin, milli mücadele için ne demek olduğunu şu sözlerle ortaya koyuyordu (Kökyay, 2003, s. 100): “Bugünkü güç durumda yurdumuzu çözülmek ve çökmek tehlikesinden kurtarmak için alınması gereken tedbirleri bulup uygulamak, sayın topluluğumuzun işi olacaktır. Ancak bugünlerde de, kendi incelemelerimize ve denemelerimize dayanan konularımızı burada belirtmeyi de ödev biliyor ve faydalı görüyoruz. Gerek anayasa kurallarına, gerek tarihteki benzerlerine, gerek günümüzde bizimkine benzer koşullar içinde dă̆ılıp gitmeye yüz tutmuş ulusların, dolayısıyla verdiği ibret derslerine göre, ülkeyi 
parçalanmaktan ve çözülmekten kurtarmak için, hemen ulusun bütün güçlerini esaslı kurallar ve koşullarla birleştirip kaynaştırmaktan başka yol yoktur. Peki bunun biçimi nasıl olması gerek? İş işte buradadır. Yasaya aykırı ve sorumsuz güçlerin başa geçmesi ile devlet güçleri birleştirilebilmiş olsa bile, bunun istendiği gibi sürdürülemediğini bilirsiniz. Aslında, yüce meclisimizin varlığı da her şeyden önce yasaya uymanın ve sorumluluk taşımanın ulusça istendiğinin belgesidir. Bunun içindir ki yüce meclisinizde toplanmış olan yüce meclis istemine dayanarak; sorumluluk bilinci ile yasaları yürütecek ve yine sayın topluluğunuzda kendini gösteren ulusal vicdanın mahkemesinde denetlenip hüküm giydiğini bilecek bir gücün, bir kuruluşun işleri yürütmesi gerekmektedir.

....Yüce meclisimiz, sadece denetlenip incelemekle yetinecek bir "mebuslar meclisi" değildir. Bunun içindir ki yalnı yasama erkini yerine getirmekle, yalnı kanun yapmakla, yalnız ulusun alınyazısını görüp yorumlamakla kalmayacak, bu alınyazısını yeniden yazmak ve gerçekleştirmek, baş ödevi olacaktır ve artık yüce meclisimizin üstünde ve dışında başka bir güç yoktur (Çağlar, 1968, s. 65-68)." Bu güç milli meclisin varlığı, milli şuurun temsili açısından şarttır. Türkiye Cumhuriyeti Devleti'nin temelinin atıldı̆̆ı, Türkiye Büyük Millet Meclisi'nin 100. yılını kutladığımız Ulusal Egemenlik ve Çocuk Bayramı sadece çocuklara değil, egemenliğin millete ait olduğu bilinci ve şuuru içinde tüm halkımıza armağan edilen bir bayramdır.

\section{Nisan Ulusal Egemenlik ve Çocuk Bayramı Belgesel Film Çözümlemesi Çalışmanın Problemi}

Türkiye Cumhuriyeti'nin sigortası olan Cumhuriyet'e giden yolun, Milli egemenlikten geçtiğini bilmek ve konuya ilişkin çocukların ve gençlerin milli şuur bilinci ve ulusal egemenlik konusundaki tutumlarının oluşması ve gelişimini sağlamak çalışmanın problemini oluşturmaktadır.

\section{Çalışmanın Amacı}

$\mathrm{Bu}$ çalışmanın amaçları, Türkiye Cumhuriyeti vatandaşlarının, Cumhuriyet'in kurulmadan önceki süreci, Kurtuluş Savaşı yıllarını, Cumhuriyet'in kuruluşu için verilen mücadeleyi, Türkiye Büyük Millet Meclisi açılmadan önceki yıllarda ülkenin toplumsal yapısını, geçmişini ve bugününü bilinçli bir biçimde yorumlayabilmesi ve geleceğe güvenle bakabilmesini sağlayacak milli bilinç ve milli şuurun gelişimine katkı sağlamaktır.

\section{Çalışmanın Önemi}

Bu çalışma, Türkiye Cumhuriyeti vatandaşlarının ulusal ve milli egemenliğinin yegane temsil makamı olan Türkiye Büyük Millet Meclisi çatısının ne kadar önemli, demokrasi ve Cumhuriyet kazanımlarının ne kadar değerli olduğunun bilinmesi, öğrenilmesi, hatırlanması ve hatırlatılması açısından önemlidir.

\section{Çalışmanın Yöntemi}

23 Nisan Ulusal Egemenlik ve Çocuk Bayramı Belgesel Filmi'nin çözümlemesinde gösterge bilimsel analiz yöntemi kullanılmıştır. Barthes (2009, s. 87), gösterge bilimsel araştırmanın, farklı yapısal etkinliklerin, gözlemlenen konuların bir taslağını üretmeye yönelik, dil dışındaki anlamlama dizgelerinin işleyiş̧ini belirleyip ortaya koymak amacını taşıdığını söylemektedir. Bu çalışmada Barthes'in sözünü ettiği şekilde gösterge bilimsel analiz yönteminden faydalanarak 
metnin içindeki söylenmeyen/gizli mesajları ve anlamları ortaya çıkarmak üzere çözümleme gerçekleştirilmiştir. Gösterge bilimsel analizin temel kavramı olan gösterge, bir başka şeyin yerini tutan, kendi dışında bir şey gösteren her çeşit biçim, nesne, olgu vb. olarak tanımlanır (Rıfat, 1990, s. 85). Belgesel filmlerde anlatılmak istenen ve çağrışım yoluyla gönderme yapılan kavram gösterilen, bu kavramı çağrıştıran sembol, sözcük, resim vb. ise gösterendir. Belgesel filmlerde her sahne bir gösterge içermektedir. Göstergeler, gördüğ̈̈müz ve görenin ardındaki gerçeği anlamak ve yorumlamak için kullanılan bir anlamlandırma biçimidir (Agocuk, 2013, s. 31). Belgesel filmlere yönelik gösterge bilimsel bir çözümleme yapılmasının nedeni bu filmlerde göstergelerin açık ve net bir biçimde görülememesidir. Yapılacak çözümlemeyle bu göstergelerin anlamları ortaya çıkarılarak sorgulanabilir hale gelmektedir. 23 Nisan Ulusal Egemenlik ve Çocuk Bayramı Belgesel Filmi’nin çözümlemesinde, belgesel filmin içinde gizlenmiş, söylenmeyen anlamların bulunup ortaya çıkartılması amaçlanmış ve analiz bu çerçevede yapılmıştır. Çalışmanın evrenini 2020 yılında "https://www.youtube.com/" sitesinde yer alan Milli Egemenlik üzerine hazırlanmış belgeseller oluşturmuştur. Yönetmenliğini Hacer YILDIZ'ın yaptığı 23 Nisan Ulusal Egemenlik ve Çocuk Bayramı Belgesel Filmi amaçlı örneklem kapsamında çalışmaya dahil edilmiştir. Verilerin toplanmasında "https://www.youtube.com/" da yayınlanan Milli Egemenlik temalı belgesel fillmler çalışmaya alınmıştır. 23 Nisan Ulusal Egemenlik ve Çocuk Bayramı Belgesel Filmi verilerinin analizinde milli egemenlik ve tarih bilinci referans olarak alınmıştır. Çözümleme göstergebilim analiz yöntemine göre yapılmıştır.

\section{Nisan Ulusal Egemenlik ve Çocuk Bayramı Belgesel Filmi'nin Künyesi}

Genel Koordinatör: Oğuz ERBİL

Tasarım Koordinatörü: Yüksel BULUT

Yapım Koordinatörü: Abdülkadir ULUÇ ve Kubilay MURATAL

Kamera: Şükrü ERDOĞAN ve Mirhan AKIN

Jenerik: Sezai MERCAN

Müzik Seçimi: Ebru ÖZYILMAZ

Metin Yazarı: Adem UYSAL

Öğretim Süreçleri Tasarımcısı: Mehtap ŞİMŞİR ÖĞE ve Nilüfer NORMAN KURT

Yönetmen: Hacer YILDIZ

Yapım: MEB Eğitek (Milli Eğitim Bakanlığı Eğitim Teknolojileri Genel Müdürlüğü)

Yapım Yılı: 2005

Süre: 11 Dakika 20 Saniye

\section{Nisan Ulusal Egemenlik ve Çocuk Bayramı Belgesel Filmi'nin Konusu}

23 Nisan Ulusal Egemenlik ve Çocuk Bayramı Belgesel Filmi Mustafa Kemal'in Anadolu'da başlattığı kurtuluş mücadelesi ile başlar. Mustafa Kemal, Samsun’a çıktığı zaman halkı işgal güçlerine karşı direnmeye çağırır. Erzurum ve Sivas Kongre'leri ile halkı birleşmeye davet ederek kurtuluş mücadelesinin fitilini ateşler. Kurtuluş mücadelesinin sağlıklı yürütülebilmesi için temsil heyetine ihtiyaç vardır ve bu heyet oluşturularak başına Mustafa Kemal getirilir. Temsil heyeti kendisine çalışma merkezi olarak stratejik konumdaki Ankara'yı seçer. Atatürk, milli meclisin kurulması gerektiğine olan inancını vurgulayarak, 19 Mart 1920 tarihinde Büyük Millet Meclisi’nin açılacağını valiliklere ve kolordu komutanlıklarına duyurur. Ardından Meclis 
açılışı için hazırlıklar başlar. Ankaralılar, 23 Nisan 1920 Cuma günü Hacı Bayram Camii’nde Cuma namazını kılıp meclise gelir, dualar okunup kurban kesildikten sonra milletvekilleri meclise girerler. Düzenlenen törenin ardından Türkiye Büyük Millet Meclisi açılır. Mustafa Kemal, oy çokluğuyla Türkiye Büyük Millet Meclisi Başkanlığı'na seçilir. Aynı zamanda da yeni hükümetin başkanı olur. Yeni Türkiye Devleti'nin yönetim şekli Cumhuriyet'tir. İşgal kuvvetleri yurttan kovulana kadar bu meclis hizmet görür. Bütün milletvekilleri millet yolunda canla başla çalışır. Milli egemenlik ruhunun filizlendiği ve hedeflerine ulaştığı yerin meclis çatısı olduğuna vurgu yapılır. 23 Nisan 1924 tarihinde, 23 Nisan gününün Ulusal Egemenlik Bayramı ilan edildiği müjdesi verilir. 1929 yılından itibaren Atatürk'ün isteğiyle 23 Nisan gününün çocuk bayramı, 23 Nisan gününü içine alan hafta çocuk haftası olarak kutlanmaya başlanır. Türkiye Büyük Millet Meclisi'nin açılması ile çocukların daha özgür bir ortamda yaşamasına, gelişimine ve eğitimine imkan sağlayacak ortam oluşturulur. Kurtuluş Savaşı'nda canlarını veren Atalarımızın bunları vatanlarının geleceği için yapmış olduğuna vurgu yapılır. 23 Nisan Dünyada kutlanan ilk çocuk bayramıdır. Atatürk, çocuklara çok değer vermiştir. "Eserimdir" dediği Cumhuriyet'ini bugünün küçükleri yarının büyükleri olan çocuklara emanet etmiştir. Ülkenin gelişip güçlenebilmesinin çocukların iyi şekilde yetişmesiyle sağlanabileceğine inanmıştır. Milli eğitim işleriyle yakından ilgilenmiş, gezilerinde okullara uğramıştır. 1979 yılından beri uluslararası çocuk şenliğine dönen milli egemenlik sevincini tüm dünya çocukları tatsın diye, her 23 Nisan'da dünyanın farklı ülkelerinden çocuklar törenlere davet edilmeye başlanmıştır. 23 Nisan Ulusal Egemenlik ve Çocuk Bayramı dünya çocuklarının bayramına dönüşmüştür. Çocukların bugünün neşesi geleceğin teminatı olduğu filmde yoğun olarak vurgulanmıştır. Milli egemenlik mücadelesi ile başlayan sürecin bayram coşkusuna dönüştüğü anlatılmıştır.

\section{Nisan Ulusal Egemenlik ve Çocuk Bayramı Belgesel Filmi'nin Gösterge Bilim Analiz Yöntemine Göre Çözümlemesi}

23 Nisan Ulusal Egemenlik ve Çocuk Bayramı belgesel filmini, tarihe 1şık tutacak bir belge olarak görmek mümkün müdür? 23 Nisan Ulusal Egemenlik ve Çocuk Bayramı belgesel filminin çekimleri film kameraları ile mi yapılmıştır? Belgesel filmin çözümüne bu soruların cevabını arayarak başlamak doğru olacaktır. Film, peliküllerin arasında 23 Nisan Ulusal Egemenlik ve Çocuk Bayramı Belgesel Filmi’nin içinden alınmış enstantaneler ile başlayınca izleyicisi acaba film kamerası ile çekilen bir film mi izleyeceğiz hissine kapılmış olabilir. Oysaki filmin video kamera ile çekildiğini film başladıktan sonra görmek mümkündür. Bu soru neden önemlidir? Çalışmaya örnek olarak alınan yüz yıl önce yaşanmış bir tarihsel olayın belgesel film olarak çekilmesinden dolayı. Belgesel film olarak çekimi yapılan 23 Nisan Ulusal Egemenlik ve Çocuk Bayramı filmini tarih bilincinin gelişimi, milli şuurun oluşumu, ulusal egemenlik olgusunun öğrenilmesi adına değerli bulmak gerekir. Belgesel film başladıktan sonra görüyoruz ki arşiv görüntülerinin, gazete küpürlerinin, fotoğrafların ağırlıkta olduğu görüntülere yer veren bir belgesel izledi seyirciler.

Çözümlemesi yapılan belgesel filmin içinde milli şuur, tarih bilinci, ulusal egemenlik ve cumhuriyet kavramlarının çalışmanın temelini oluşturduğu görülür. Bu kavramların tamamı filmin içinde bir bütün içinde sunulmuştur. Bütünlüklü yapıyı açıklamakta fayda vardır. Bütünlüklü yapıyı sağlayan belgesel filmin anlatı yapısıdır. Belgesel filmin anlatı yapısı içinde bütünlüğü sağlayan unsurlar, belgesel filmin jeneriği (açılış), gövdesi (birlik, çeşitlilik, tempo ve doruk nokta) ve kapanışın gereksinimi karşılayıp karşılamadığı sorularına verilecek cevapta 
gizlidir. 23 Nisan Ulusal Egemenlik ve Çocuk Bayramı Belgesel filminin açılışında, filmin içerisinden alınan 8 farklı sahne birleştirilerek, piyano müziğinin eşliğinde filmin ruhuna, dokusuna, temasına uygun bir tanıtıcı açılış (jenerik) gerçekleştirilmiştir.

23 Nisan Ulusal Egemenlik ve Çocuk Bayramı Belgesel filminde sunucu-seslendiren kullanılmıştır. Bülent Yıldıran ismindeki sunucu-seslendiren tarihi olayların gelişimini zaman zaman ekranda görünerek sunmuş, zaman zaman Bülent Beyin konuşmalarının üstüne video arşiv görüntüler gelmiştir. Bülent Bey'in haricinde ekranda çekimlere katılan iki çocuktan söz etmek gerekir. Yaklaşık on bir, on iki yaşlarında olan çocuklardan ilki erkek çocuk Mert Özdemir, kız çocuk Çisel Aras’tır. Mert ve Çisel'de Bülent Bey gibi tarihi olayların gelişimini zaman zaman ekranda görünerek, zaman zaman video arşiv görüntülerin üstüne konuşarak yapmışlardır. Bülent Bey'in de, Çisel'in de, Mert'in de aynı biçimde sunuş yapması birliği sağlayan birinci adımdır. 23 Nisan Ulusal Egemenlik ve Çocuk Bayramı Belgesel filminde film boyunca konuşma metinleri ile konuşmaların üstüne gelen arşiv görüntülerin senkronize olarak sunumuna dikkat edilmiştir. Belgesel filmde birlikli yapıyı sağlayan en önemli unsur metin ile görüntü arasındaki uyumdur. Bu noktada da birlikli yapının korunmasına dikkat edilmiştir. 23 Nisan Ulusal Egemenlik ve Çocuk Bayramı Belgesel filminde, işlenen temalar milli egemenliğe giden kurtuluş mücadelesi ile başlayıp, meclisin açılışı için yapılan hazırlıklar, meclise milletvekillerinin gelişi, halkın sokaklarda ve meclis önündeki coşkusu, meclisin açılışında yapılan konuşmalar, Mustafa Kemal'in yemini, ilk meclis başkanının seçilmesi, ilk hükümetin kuruluşu ile devam etmiş, bu noktada da birlikli yapının korunmasına özen gösterilmiştir. 23 Nisan Ulusal Egemenlik ve Çocuk Bayramı Belgesel filminde çeşitliliği sağlayan unsurlar fazladır. Çeşitliliği sağlayan ilk unsur, görüntü çeşitliliğidir. Mecliste sunucu-seslendiren Bülent Bey'in, Çisel'in, Mert'in sunumları çeşitliliğin ilk adımını oluşturmaktadır. Arşiv görüntülerin, video kamera ile yapılan çekimlerin siyah beyaz ve renkli olması, filmde 24 Nisan 1920 tarihli gazete küpürünün ve fotoğrafların kullanılması, görsel açıdan çeşitliliğin sağlanmasında etkili olmuştur. 23 Nisan Ulusal Egemenlik ve Çocuk Bayramı Belgesel filminin metin kısmında, milli şuur, kurtuluş mücadelesi, meclisin aç1lışı için sarf edilen emek, ulusal egemenlik çabaları, Mustafa Kemal'in liderlik ve koordine yeteneği, meclis binasının açılışı için yapılan hazırlık çalışmaları, meclisin açılışı, yemin töreni, meclis açıldıktan sonra halkın coşkusu, Türkiye Büyük Millet Meclisi'nin açılışı ile Cumhuriyet'e uzanan yolculuk, Mustafa Kemal'in 23 Nisan'1 Ulusal Egemenlik ve Çocuk Bayramının ilan edilerek dünya çocuklarına armağan edilişinin konu edilmesi çeşitliliği sağlayan en önemli taraflardır. 23 Nisan Ulusal Egemenlik ve Çocuk Bayramı Belgesel filminin temposunu belirleyen öğe sayısı fazladır. Belgesel film başlarken açılış (jenerik) ta peliküllerin kullanılması, arşiv görüntülerinin çeşit ve sayıca fazla olması, gazete küpürlerinden ve fotoğraflardan faydalanılması, üç sunucunun kullanılması, ses efektleri, müzik, kameranın hareketleri, sunucuların hareketleri temponun ayarlanmasında etkili olmuştur. 23 Nisan Ulusal Egemenlik ve Çocuk Bayramı Belgesel filminin doruk noktası Meclis'in açıldığı andır. Mustafa Kemal'in yemin ettiği fotoğraf görüntüsü, filmin ruhunu, temasını, amacını anlatan en güzel andır.

23 Nisan Ulusal Egemenlik ve Çocuk Bayramı Belgesel filminin kapanışında sunucuseslendiren Bülent Bey'in, Çisel'in ve Mert'in kapanış anonsu filmin karakterine uygun gerçekleştirilmiştir. Kapanış anonsunun ardından daha önce kutlanan 23 Nisan Ulusal Egemenlik ve Çocuk Bayramı etkinliklerinden alınmış görüntülerin ekranda 30 saniye akarak, ardından yapımda görev alan kişilerin isimlerinin verilmesi, filmin sonunda ise yapımcı 
kuruluşun ve yapım yılının verilmesi uygun olmuştur. Film boyunca müziklerin filmin temposunu belirlemede ve izleyicilerin dikkat yoğunluğunun ayarlanmasında iyi bir şekilde kullanıldığını belirtmek gerekir.

Filmin anlatı yapısı üzerine yapılan değerlendirmenin ardından gösterge bilimsel analize göre 23 Nisan Ulusal Egemenlik ve Çocuk Bayramı Belgesel filminin çözümüne bakıldığında neler görülmektedir? Filmin başında ekranda pelikül yaklaşık 15 film karesine bölünmüştür. Pelikül sarı renktedir. Pelikülün altında yer alan siyah, beyaz, gri rengin ağırlıkta olduğu görüntüde çocuklar, caddeler, bayraklar ile süslemiş binalar, Atatürk gelir ekrana. Görüntülerin üstünde 23 Nisan Ulusal Egemenlik ve Çocuk Bayramı yazmaktadır. Peliküller zincirleme geçiş ile ekrandan giderken kız ve erkek çocukların yer aldığı bayram coşkusu gelir görüntüye.
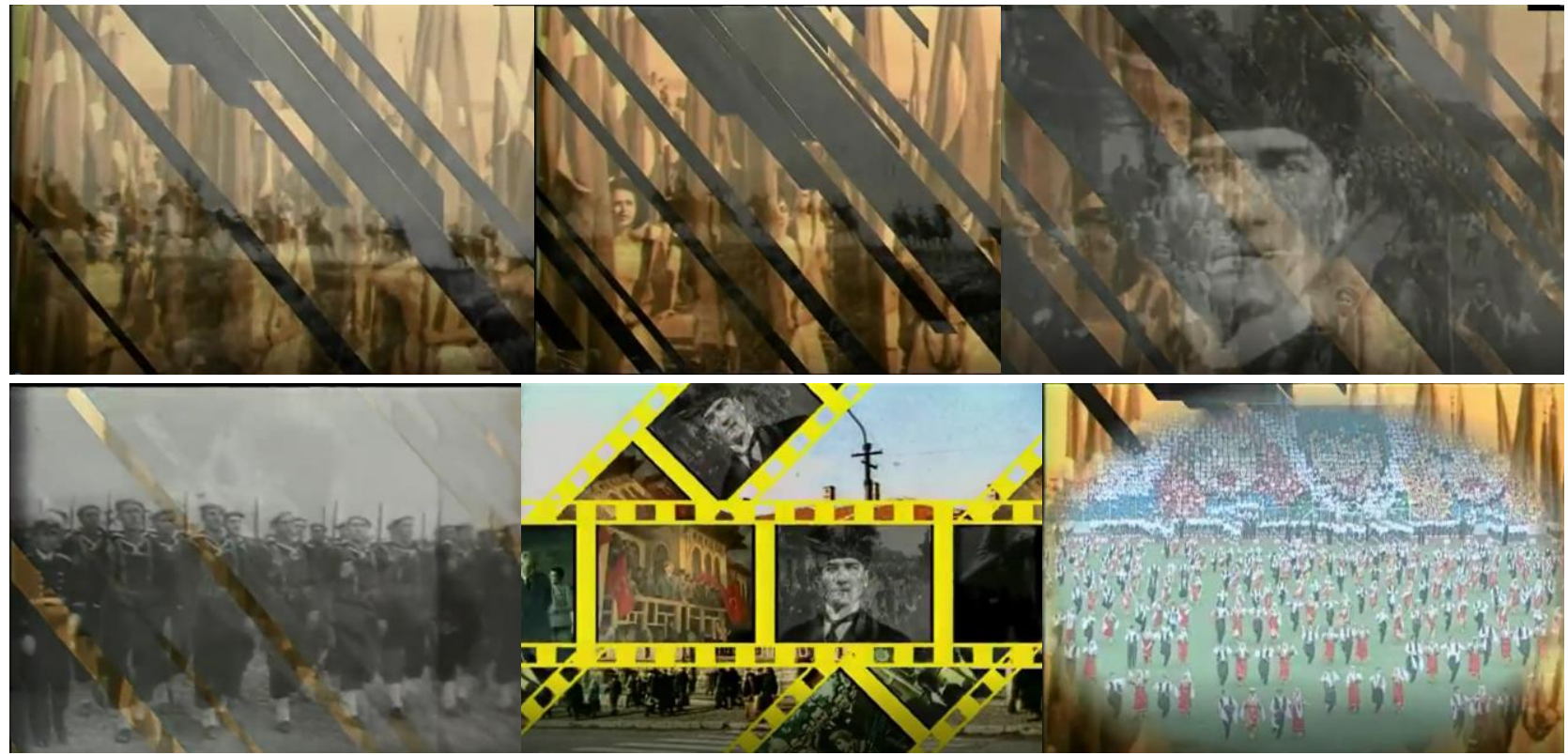

Albüm 1. 23 Nisan Ulusal Egemenlik ve Çocuk Bayramı Belgesel Filminin Açılışı (Jenerik)

Albüm 1'de görülen Türk bayrağı bağımsızlığı, Mustafa Kemal güveni, coşku ile yürüyen gençler coşkuyu ve yürüyen askerler gücün temsilidir. Temsil edilen Türkiye Cumhuriyeti Devleti'nin özünü, ruhunu oluşturan değerlerdir (Tablo 1).

Tablo 1. Göstergebilim Analizi

\begin{tabular}{|c|c|c|}
\hline Gösterge & Gösteren & Gösterilen \\
\hline Nesne & Türk Bayrağı & Bağımsılık \\
\hline İnsan & Atatürk & Güven \\
\hline Eylem & Yürüyen Gemçler & Coşku \\
\hline Eylem & Yürüyen Askerler & Güç \\
\hline
\end{tabular}


Albüm 2'de stadyumda folklor oynayan kız ve erkek çocuklar, ardından yürüyüş yapan kız ve erkek çocuklar gelir ekrana. Kesme ile Atatürk'ün mozalesine çelenk bırakan bir küçük kız çocuğu gelir görüntüye. Ardından stadyumda coşkulu çocuklar, yavru kurt olmuş minik kız ve erkek çocuklar bir gökkuşağı oluşturur ekranda.
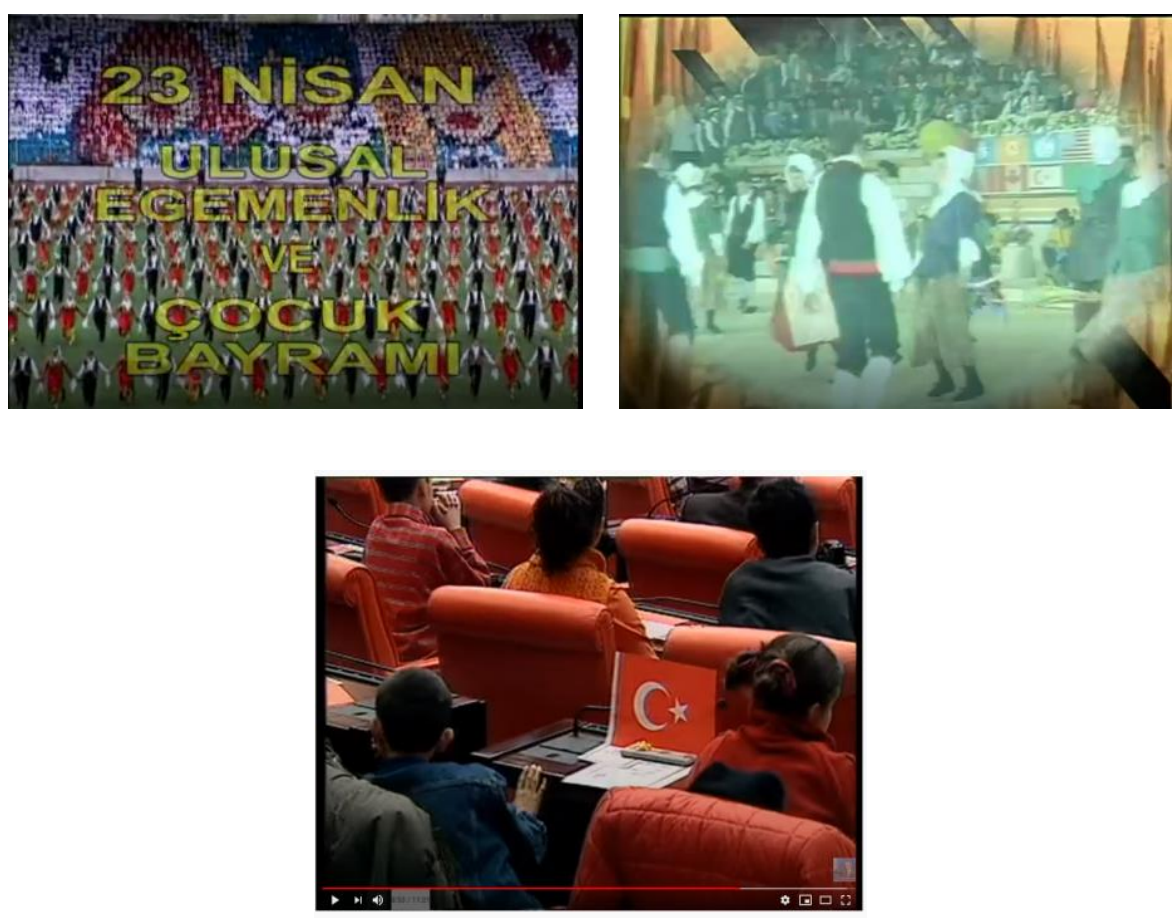

\section{Albüm 2. 23 Nisan Ulusal Egemenlik ve Çocuk Bayramı Belgesel Filmi Giriş Sahnesi}

$\mathrm{Bu}$ coşkunun devamında kırmızı koltuklarda oturan çocuklar kapalı spor salonunda bayram kutlamaktadır. Beyaz kıyafetleri, ellerinde Türk bayrakları ile tören kıtasının önünden sevinçle geçen çocukların görüntüsünün devamında, kırmızı beyaz giyimli kız çocukları ile siyah beyaz giyimli erkek çocukların gösterilerinin üstüne; 23 Nisan Ulusal Egemenlik ve Çocuk Bayramı yazısının bindirmesi gelir. Burada gösterilen Türkiye Cumhuriyeti Devleti'nin istikbali, egemenliği, bayram coşkusudur (Tablo 2).

Tablo 2. Göstergebilim Analizi

\begin{tabular}{lll}
\hline Gösterge & Gösteren & Gösterilen \\
\hline İnsan & Gösteri Yapan Çocuklar & İstiklal \\
İnsan & Folklor Oynayan Çocuklar & Coşku (Kutlama) \\
Nesne & Türk Bayrağ & Egemenlik \\
- & &
\end{tabular}


Meclis binasında konuşmasını yapmak üzere kürsüye gelen Mustafa Kemal Paşa, kürsüdeki yerini alırken ilk meclisin mebusları da meclis salonundadır. Fotoğraf siyah beyazdır ancak coşku yoğundur. Mustafa Kemal Paşa konuşmasına başlarken meclis salonundaki fotoğraf karesinden sokaklarda halkın coşkusunu gösteren fotoğraflara döner görüntü. Çocuk, genç, yaşlı, kadın, erkek, kısa pantolon giyen, kazak giyen, ceketli, gömlekli, resmi kıyafetli halkın coşkusunu gösteren görüntülerin arasında Mustafa Kemal Paşa konuşmasına başlar.

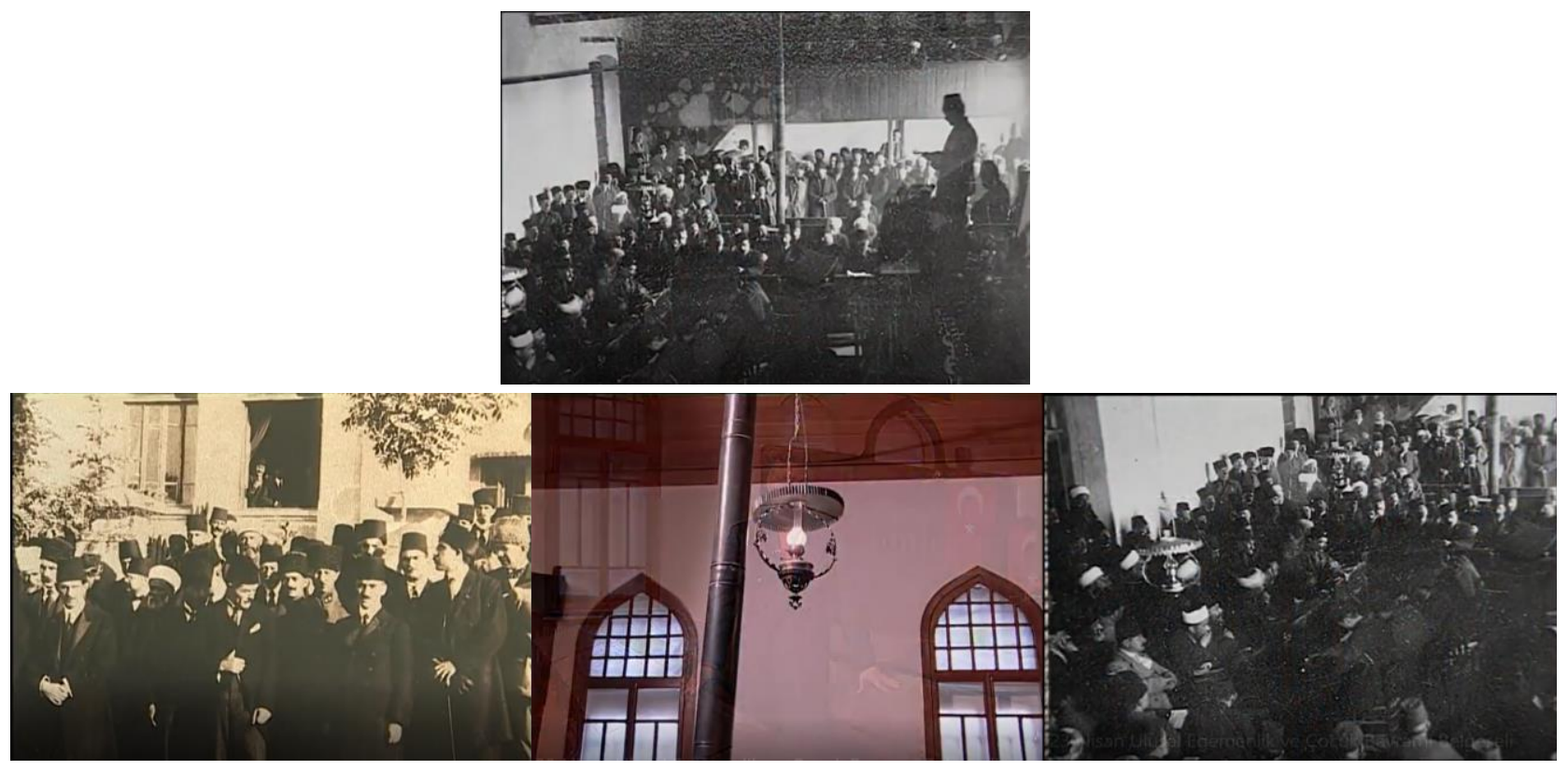

Albüm 3. Atatürk’ün Meclis’te Yemin Töreni

Albüm 3'de Mustafa Kemal Paşa milli bağımsızlığın önemine vurgu yapar. Milli bağımsızlık uğrunda milletim ile birlikte çalışacağım diyerek and içer. Mustafa Kemal liderliğin, mecliste yer alan milletvekilleri ve meclis salonu milli egemenliğin ve bağımsızlığın, yaşlı, genç, çocukların yer aldığı fotoğraf karesi mutluluğun, Atatürk'ün yemin töreni Türk halkına verdiği namus sözünün temsilidir (Tablo 3).

\section{Tablo 3. Göstergebilim Analizi}

\begin{tabular}{lll} 
Gösterge & Gösteren & Gösterilen \\
\hline İnsan & Atatürk & Liderlik \\
İnsan & Mecliste Yer Alan Milletvekilleri & Bağımsılık \\
Mekan & Meclis & Milli Egemenlik \\
İnsan & Yaşli-Çocuk-Genç & Mutluluk \\
İnsan & Atatürk'ün Yemini (And) & Türk Halkına söz \\
& & verme \\
& &
\end{tabular}

Albüm 4' de Atatürk'ün askerler ve halk ile birlikte sohbet ederken ki görüntüsüne miks ile geçiş yapılır. Görüntüde Atatürk karşısındaki insanları sürekli selamlamaktadır. Fotoğraf karesinde meclis bahçesinde toplanan halk görülmektedir. Sunucu-seslendiren Bülent Yıldıran 
milletvekillerinin yemin ettiğini, 338 milletvekilinden ancak 115'inin ilk toplantıda olabildiğini söyler. Meclisin en yaşlı vekili olan Sinop milletvekili Şerif Bey’in geçici başkanlığa seçildiğini, Şerif Bey'in açılış konuşmasını yapmasından sonra kürsüye Mustafa Kemal'in geldiğini, Mustafa Kemal'in genel durum hakkında açıklamalar yaptığını söyler. Yıldıran konuşmasının devamında, Mustafa Kemal, oy çokluğuyla Türkiye Büyük Millet Meclisi Başkanlığı'na seçildiğini, aynı zamanda da yeni hükümetin başkanı olduğunu söyler. Bu yeni yönetimin Türkiye Büyük Millet Meclisi hükümeti adını aldığını ifade eder. (Bu yeni yönetim Türkiye Büyük Millet Meclisi hükümeti adını aldı anonsu ile görüntüye İkdam gazetesinin konu ile ilgili haberi girer.)

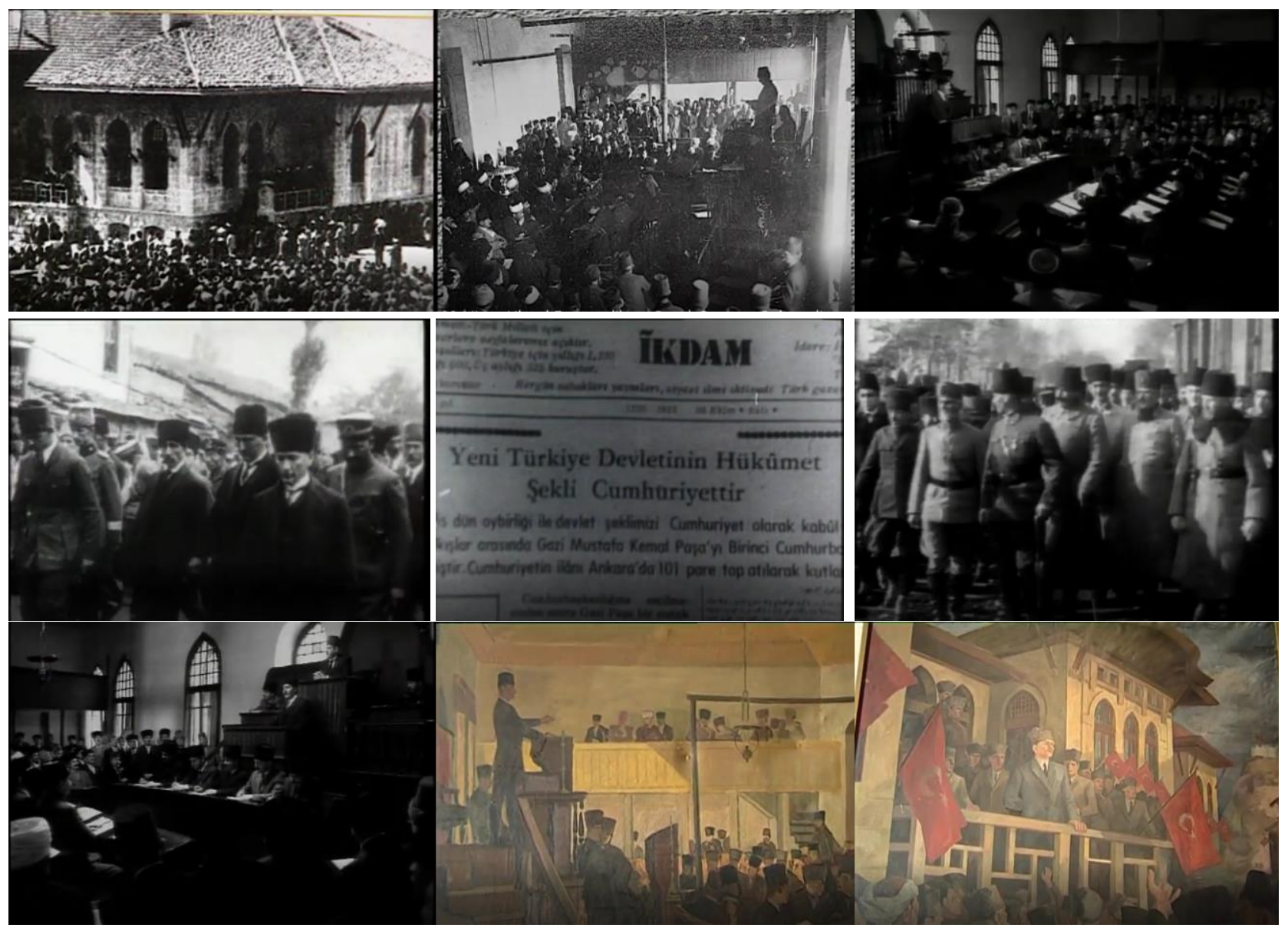

Albüm 4. Türkiye Büyük Millet Meclisi’nin Açılışı ve Halkın Coşkusu

Manşette, "Yeni Türkiye Devleti'nin hükümet şekli Cumhuriyet'tir" yazmaktadır. Mustafa Kemal'in halk ile kucaklaşmasını Cumhuriyet sevinci ile, meclis binası ve milletvekillerinin fotoğraflarını meclisin milli bağımsızlığın temsil yeri olarak, gazetenin "Yeni Türkiye Devleti'nin hükümet şekli Cumhuriyet'tir" haberini yeni yönetim biçiminin Cumhuriyet olduğu biçiminde okumak mümkündür (Tablo 4). 


\section{Tablo 4. Göstergebilim Analizi}

\begin{tabular}{lll} 
Gösterge & Gösteren & Gösterilen \\
\hline Mekan & Meclis & Cumhuriyet \\
Mekan & Meclis & Meclis Aç1liş1 \\
İnsan & Halk & Demokrasi \\
Nesne & Gazete & Haber \\
& &
\end{tabular}

Meclis'in Cumhuriyeti simgeleyen önemli bir kurum olduğunu bilerek, gazetedeki başlık ve başlığın altında yer alan haberi ise Cumhuriyet'in önemli bir kazanımı olarak demokrasi biçiminde değerlendirmek mümkündür. İşgal kuvvetleri yurttan kovulana kadar bu meclis hizmet görür. Bütün milletvekilleri millet yolunda canla başla çalışır. Milli egemenlik ruhunun filizlendiği ve hedeflerine ulaştı̆̆ yer meclis çatısıdır. Bunun içindir ki kurucu meclis Türk milleti adına çok önemli, çok kıymetli şeyler yapmışlardır. Yapılan en değerli şey, tam bağımsız, tam egemen bir devleti bizlere armağan olarak bırakmış olmalarıdır.

Albüm 5'de Meclis balkonuna Türk bayrağı asan Türk askerleri bağımsızlı̆̆ı, Ankara'nın tepeden görüntüsü başkenti, otomobil medeniyeti, bez fabrikası gelişmişliği, laboratuvar bilimselliği, senfoni orkestrası sanatı, ilköğretim okulu bilimi gösteren karelerdir (Tablo 5).

Tablo 5. Göstergebilim Analizi

$\begin{array}{lll}\text { Gösterge } & \text { Gösteren } & \text { Gösterilen } \\ \text { Mekan } & \text { Ankara } & \text { Başkent } \\ \text { İnsan } & \text { Asker } & \text { Kuvvet-Güç } \\ \text { Mekan } & \text { Bez Fabrikası } & \text { Gelişmişlik } \\ \text { Mekan } & \text { Laboratuvar } & \text { Bilimsellik } \\ \text { Nesne } & \text { Keman } & \text { Sanat } \\ \text { Mekan } & \text { Okul } & \text { Bilim } \\ - & \end{array}$



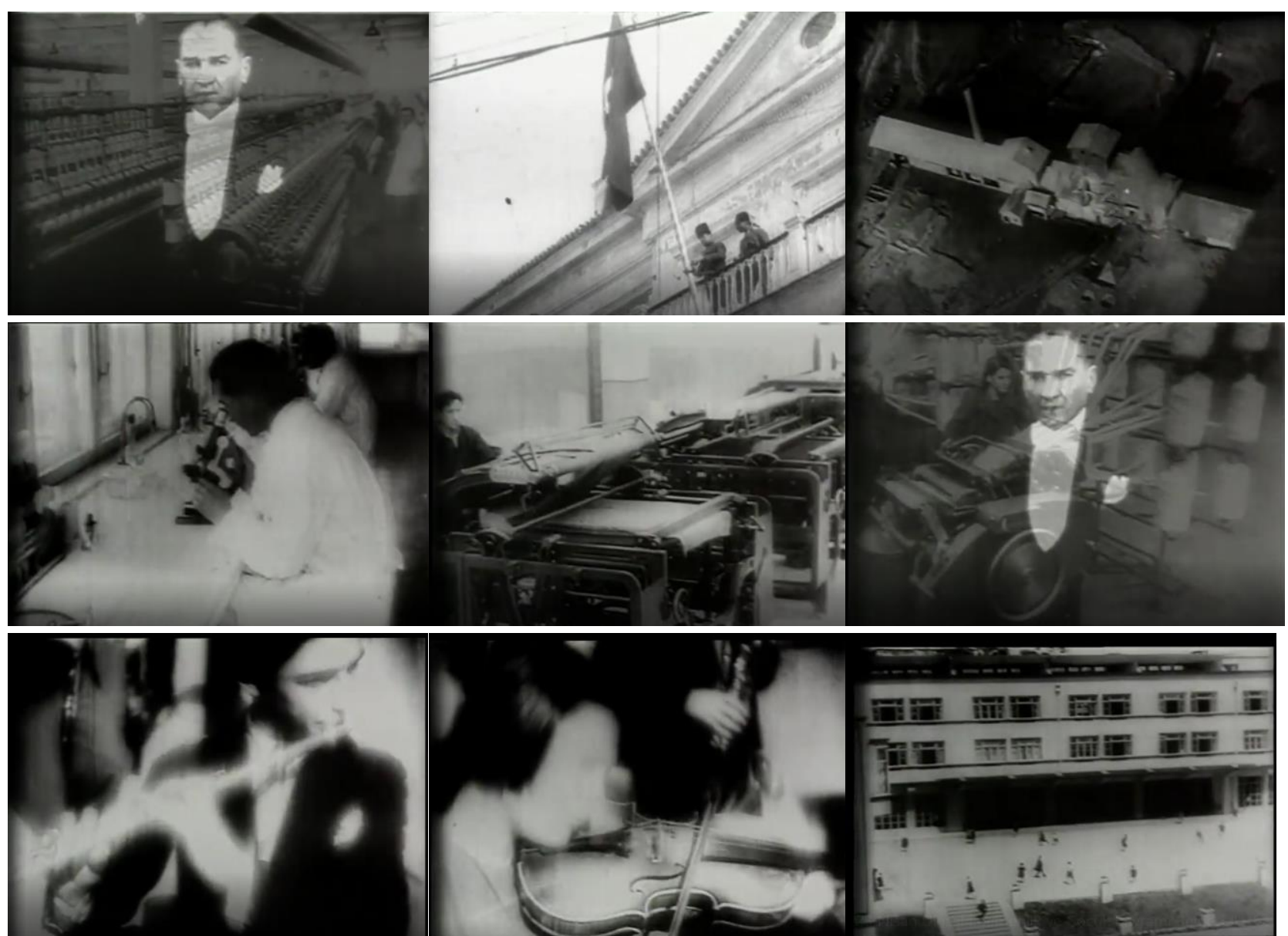

\section{Albüm 5. Türkiye Cumhuriyet’inin Kuruluş Yıllarında Kültür, Sanat, Eğitim ve Teknolojik Alandaki Gelişimi}

Gösterilenleri sadece göstergelerin temsil vasıtası olan gösterenler üzerinden değerlendirmemek gerekir. Cumhuriyet'in gelişimini işaret eden fotoğraflardan askerlerin meclis balkonuna bayrak asarkenki görüntünün anlamını farklı şekillerde okumak mümkündür. Mustafa Kemal'in Samsun'a çıkışı ile başlayıp, halkı işgal güçlerine karşı direnmeye çağırışı, Erzurum ve Sivas Kongreleri ile halkı birleşmeye davet ederek kurtuluş mücadelesinin ilk işaretini vermesi, milli mücadelenin ne kadar zor kazanıldığını, ne kadar önemli, ne değerli olduğunu göstermektedir. Bez fabrikası ekonomik alandaki bağımsızlık ve gelişmişlik açısından, laboratuvar bilimsel alandaki ilerleme açısından, keman sanata verilen değer açısından, okul ilim, irfan, gelecek açısından çok önemli birer gösterge aracı olarak, Cumhuriyet ile elde edilen kazanımlar olarak değerlendirilebilir. 


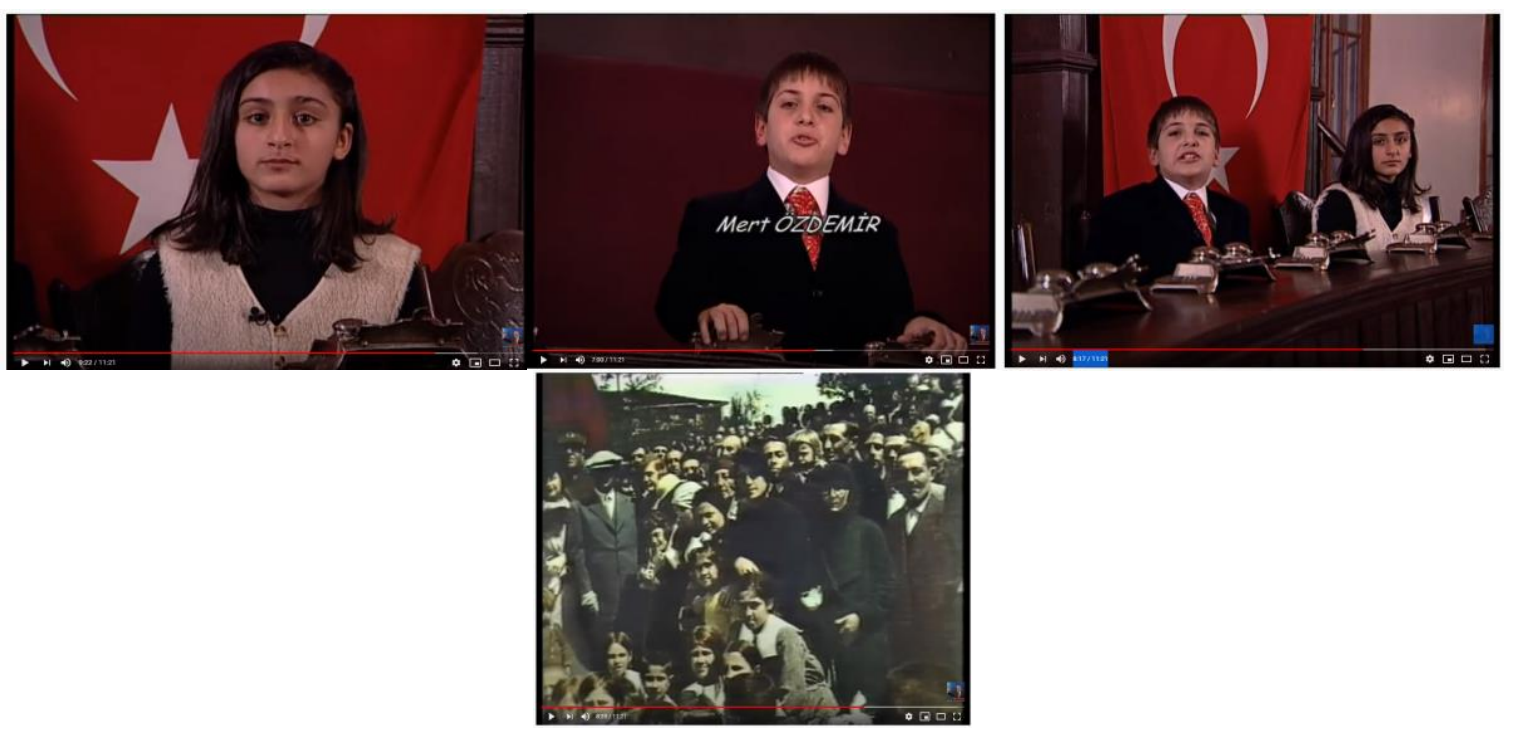

Albüm 6. Türkiye Büyük Millet Meclisi'nin Açılış Coşkusu

Albüm 6'da Çisel'in ve Mert'in görüntüleri istikbalimizin, meclis kürsüsü bağımsızlığımızın, halk bayram coşkusunun ifade edildiği gösterilenlerdir (Tablo 6).

\section{Tablo 6. Göstergebilim Analizi}

\begin{tabular}{lll} 
Gösterge & Gösteren & Gösterilen \\
\hline İnsan & Mert ve Çişil & İstiklal \\
Nesne & Meclis Kürsüsü & Bağımsılık \\
İnsan & Halk & Gelecek \\
- & &
\end{tabular}

Güçlü bir devlet yapısının olmasını arzulayan Atatürk, Türk Devleti'nin tam bağımsız, egemenliğin kayıtsız şartsız millete ait olmasını isteyerek, tam bağımsızlı̆̆ istemiştir. $\mathrm{Bu}$ yüzden de Cumhuriyet kurulana kadar iç ve dış güçlere karşı amansız bir mücadele yürütmüştür. Yürütülen mücadelenin milli bağımsızlık olmasını isteyerek Türkiye Büyük Millet Meclisi’nin kuruluşuna büyük önem vermiştir.

23 Nisan 1920 Türkiye Büyük Millet Meclisi'nin açıldığı gündür. O gün egemenliğin kayıtsız şartsız millete ait olduğunun tescillendiği gündür. İdare usulünün halkın kendi kendini idare etmesi esasına dayanan yönetim anlayışının temelinin atıldığı gündür.

\section{Sonuç}

23 Nisan Ulusal Egemenlik ve Çocuk Bayramı Belgesel Filmi tanıtıcı bir açılışla başlamıştır. Film'in açılışında piyano müziğinin eşliğinde 23 Nisan Ulusal Egemenlik ve Çocuk Bayramı Belgesel Filmi'nin ruhuna, dokusuna, temasına uygun bir tanıtıcı açılış (jenerik) ile giriş yapılmıştır. 23 Nisan Ulusal Egemenlik ve Çocuk Bayramı Belgesel Filmi'nin gövdesinde birlikli bir yapı vardır. Filmde birliği sağlayan unsurlar, metin ile görüntü arasındaki uyum, görüntüler arasındaki ahenk öncelikli olarak göze çarpanlardır. Gövde içinde çeşitliliği sağlayan unsur olarak, filmin jeneriği (açılış), sunucu sayısı, ses efektleri, arşiv görüntülerinin çeşitliliği, 
kamera hareketleri, kişilerin hareketleri olarak sıralanabilir. Filmin doruk noktası Türkiye Büyük Millet Meclisi'nin açlışı ve Mustafa Kemal'in yemin ettiği andır. Programın kapanışına bakıldığında genel hatları ile kapanışın gerekliliklerini yerine getirmiştir. Belgeselin kapanışında yapım ekibinin, yapımcı kurumun ve yapım yılının KJ'leri verilerek kapanışın gereklilikleri yerine getirilmiştir. Filmin bütününe bakıldığında, söz ve görüntü arasında uyumun olduğu görülür. Filmde metin içinde temaya ve konuya uygun olarak milli şuur, milli bilinç, milli egemenlik konuları ele alınmıştır. Türkiye Büyük Millet Meclisi'nin açılışına kadar ki süreçte Atatürk'ün Samsun'a çıktığı zaman halkı işgal güçlerine karşı direnişe çağırması, Erzurum ve Sivas Kongrelerinde halkın tek vücut olmasını istemesi, Türkiye Büyük Millet Meclisi’nin açılışına kadar ki süreçte milli mücadelenin en önemli adımları olmuştur. Türkiye Cumhuriyeti Devletinin sigortası ve teminatının Türkiye Büyük Millet Meclisi olduğu net bir şekilde açıklanmıştır. Türkiye Büyük Millet Meclisi açılırken halkın Meclis'e gösterdiği teveccüh ve destek filmde göze çarpan noktalar olarak hafizalarda yer etmiştir.

23 Nisan 1920 tarihinde Türkiye Büyük Millet Meclisi açıldıktan sonra, halkın milli egemenlik konusundaki coşkusu, mutluluğu her yıl kutlanan 23 Nisan Ulusal Egemenlik ve Çocuk Bayramlarında artarak devam etmektedir. İlelebet devam edecektir. Üzerinden yüz y1l geçmesine rağmen Türkiye Büyük Millet Meclisi ilk günkü şevk, azim ve kararlılığı ile milli egemenlik ve bağımsızlığını yaşamaya ve yaşatmaya devam etmektedir.

\section{Kaynakça}

Adal1, B. (1986). Belgesel sinema. İstanbul: Hil.

Agocuk, P. (2013). Amarcord filmi özelinde göstergebilimsel film çözümlemesi ve anlamlandırma. Uluslararası Sosyal Araştırmalar Dergisi, 7(31), 7-18.

Andrew, J. D. (1976). The major film theories: An introduction. New York: Oxford University.

Aufderheide, P. (2007). Documentary film: A very short introduction. New York: Oxford University.

Aytekin, H. (2013). Türkiye'de toplumsal değişme ve belgesel sinema. (Yayımlanmış Doktora Tezi). Maltepe Üniversitesi Sosyal Bilimler Enstitüsü, İstanbul.

Barnouw, E. (1974). Documantery: History of the non-fiction film. New York: Oxford University.

Barthes, R. (2009). Gösterge bilimsel serüven. (M. Rıfat ve S. Rıfat, Çev.). İstanbul: Yapı Kredi.

Baydur, M. (2004). Sinema yazıları. İstanbul: İletişim.

Çağlar, B. K. (1968). Atatürk'ün söylevleri. Ankara: Türk Dil Kurumu, Ankara Üniversitesi.

Çakaroz, E. (2008). Belgesel sinemanın tarihsel süreç içinde geçirdiği değişim ve bu değişimin sonucu olarak televizyondaki belgesele dayalı melez program türleri. (Yayımlanmış Yüksek Lisans Tezi). Anadolu Üniversitesi Sosyal Bilimler Enstitüsü, Eskişehir.

Demir, Ü. (2015). 2000 sonrası Türk belgesel sinemasında ideoloji ve gerçeklik. (Yayımlanmış Yüksek Lisans Tezi). Ege Üniversitesi Sosyal Bilimler Enstitüsü, İzmir. 
Esen, M. (1998). Belgesel sinema ve Türkiye'de belgesel sinemanın geçirdiği evreler. (Yayımlanmış Yüksek Lisans Tezi). Marmara Üniversitesi Sosyal Bilimler Enstitüsü, İstanbul.

Göde, K. (1988). Dünden bugüne Türklerde Meclis hayat1, Ondokuz Mayıs Üniversitesi Eğitim Fakültesi Dergisi, 3, 51-62.

Kökyay, F. (2003). Atatürk'ün ifadeleriyle milli şuur ve milli şuurun oluşmasında Türk kimliğinin rolü. (Yayımlanmış Yüksek lisans Tezi). Fırat Üniversitesi Sosyal Bilimler Enstitüsü, Elazı ğ.

Morva, A. D. (2003). Belgesel sinemada nesnellik olgusu. (Yayımlanmış Yüksek Lisans Tezi). Mimar Sinan Üniversitesi Sosyal Bilimler Enstitüsü, İstanbul.

Mumcu, A., Özbudun, E., Feyzioğlu, T., Ülgen, Y., Çubukçu, İ. A. (1986). Atatürk ilkeleri ve inkilap tarihi II. Ankara: Yüksek Öğretim Kurumları.

Mutlu, E. (1995). Televizyonda program yapımı. Ankara: Ankara Üniversitesi İletişim Fakültesi.

Mükerrem, Z. (2015). Belgesel estetiği üzerine düşünceler-kuram ve uygulamalar. Konya: Literatürk Academia.

Nichols, B. (1991). Representing reality: Issues and concepts in documentary, Bloomington, IN: Indiana University.

Özden, A (2019). 19 mayıs 1919'dan Türkiye Büyük Millet Meclisi'nin açılışına. Erişim adresi: https://www.aa.com.tr/tr/turkiye/19-mayis-1919dan-tbmmnin-acilisina/1459496

Pembecioğlu, N. (2005). Belgesel film üstüne yazllar. İstanbul: Babil.

Rabbiger, M. (1998). Directing the documentary. Boston: Focal.

Rıfat, M. (1990). Dilbilim ve göstergebilimin çağdaş kuramları. İstanbul: Düzlem.

Rotha, P. (2000). Belgesel sinema. İstanbul: İzdüşüm.

Ulutak, N. (1988). Belgesel sinemanın temel özellikleri ve tarih felsefesi açısından belgesel sinemada gerçeklik. (Yayımlanmış Doktora Tezi). Anadolu Üniversitesi Sosyal Bilimler Enstitüsü, Eskişehir.

Vardar, B. (2007). Belgesel Sinemacı Bir Misyoner midir?, Belgesel sinema 2007, İstanbul: BSB Sinema Eserleri Sahipleri Birliği.

Wolf, R. (1974). The writer and the screen. New York: Morrow Quill Paperbacks.

Wollen, P. (2004). Sinemada göstergeler ve anlam. İstanbul: Metis.

Yildırım, E. (2019). Televizyon belgesel filmleri anlatı yapısının izler kitle beklentilerine etkileri ve örnek belgesel film çözümlemesi. Dördüncü Kuvvet, 2(2), 134-149.

Yıldız, H. (2005). 23 Nisan Ulusal Egemenlik ve Çocuk Bayramı Belgeseli [Video]. Erişim adresi: https://www.youtube.com/watch?v=KCzttiHTVMI 